\title{
Comparison of Misconceptions about Human Digestive System of Turkish, Albanian and Bosnian 12th Grade High School Students
}

\author{
Arzu, Çuçin'1, Sami, Özgür² \& Burcu, Güngör Cabbar ${ }^{2},{ }^{*}$ \\ ${ }^{1}$ Luciano Motroni Vocational Health High School, Kosovo \\ ${ }^{2}$ Necatibey Faculty of Education, Balikesir University, Turkey \\ *Correspondence: Necatibey Faculty of Education, Biology Education Department, Balıkesir University, Balikesir, \\ Turkey. Tel: 90-505-896-6236. E-mail: burcu.cabbar@balikesir.edu.tr
}

Received: April 18, 2020

Accepted: June 10, 2020 Online Published: June 20, 2020

doi:10.5430/wje.v10n3p148

URL: https://doi.org/10.5430/wje.v10n3p148

\begin{abstract}
Information that is different from scientific knowledge, consistent and resistant to change, can be expressed as misconceptions. Misconceptions are one of the critical factors that prevent students from understanding in Biology education. This study was conducted in Kosovo with high school 12th-grade students of three different ethnic origins. It is aimed to determine the misconceptions that students have about "Digestive System in Human" comparatively. The study was carried out with 150 12th grade students in Kosovo in the 2016/2017 academic year. The research was carried out with qualitative research techniques as a data collection tool consisting of student drawings and explanations, and true/false items used. A descriptive analysis made. The findings showed that the students had many misconceptions about the human digestive system. Some Turkish students have drawn the digestive system with the kidney and intestine compared to other ethnic groups. Albanian and Bosnian students generally draw the digestive system after the stomach for separate solids for liquids. This misconception may be related to the concept of image (prima de perception) (Bachelard, 1938). Also, cultural misconceptions stemming from language encountered. Bosnian students use the concept of "boiling" instead of "digestion".
\end{abstract}

Keywords: digestive system, misconceptions, high school students, biology

\section{Introduction}

Concepts are the connotations that occur in the mind of a person when it comes to any being or object. From this point of view, it is possible to say that concepts are shaped in the human mind as a result of experiences about events, beings, and objects and that there is a common understanding about what is mentioned (Çepni vd., 2015). In science education, concept teaching is of great importance. Concepts need to be comprehended correctly and scientifically. Otherwise, the status of the concepts changes, and they turn into information that does not have scientific foundations but is "sufficient" and "consistent" to explain its environment. This knowledge is called misconceptions in general terms and is likely to create a learning disability for the individual's subsequent learning. Misconceptions that will occur at an early age, especially in primary education, may lead to significant future learning disabilities in science education (Pelitoğlu, 2006).

There has been much research on misconceptions in science education in recent years. Researchers use the term misconception, experience-based misconceptions that result from life experiences, and misconceptions based on teaching resulting from the teaching process. Misconceptions that occur before education and are resistant to change are formed as a result of the students' affective knowledge and hereditary limitations. Instructional misconceptions, on the other hand, argue that the student's prior knowledge and the language used in expressing the concepts in teaching, and the inadequacy of the chosen teaching method are among the sources (Bilgin vd., 2003). Studies have shown that, because the misconceptions are permanent and widespread, it is difficult to overcome traditional teaching methods, and it is not sufficient for the student to develop the correct concepts (Tekkaya ve Balc1, 2003).

It is known that biology is a field where students have difficulties in understanding, and teachers have difficulties in explaining. Looking at the studies on the causes of these difficulties, subjects that biology inquire are generally intangible; teachers generally use theoretical methods, so students feel they never understand biology concepts and 
fail (Akpınar, 2006; Kılıç \& Sağlam, 2004). The investigation of children's knowledge about the concept in Biology, especially in the Human Digestive System Topic, formed has gathered momentum in pre-school education research in the last 30 years (Ahi, 2017). Through the amount of research, many researchers found that the biological knowledge viewpoint by the students is always increasing. There is a paucity of research that biological knowledge is ever-changing over time, and depending on the developmental process (Roswati, Rustaman, \& Nugraha, 2019, Geerdts, Van de Walle, \& LoBue, 2015).

In the literature, it is revealed that there are learning difficulties about photosynthesis, osmosis-diffusion, cell divisions, ecology, evolution, digestive system, respiratory system, excretory system, nervous system and hormones, circulatory system, enzymes and genetics related to biology studies are available (Giordan \& Vecchi, 1987; Cerrah, Özsevgeç, \& Ayas, 2005; Selvi \& Yakışan, 2004; Tekkaya et al., 2000; Özgür \& Pelitoğlu, 2008; Güngür \& Özgür, 2009; Güngör, 2009). In the majority of studies in the field of biology, there is a focus on evolution, photosynthesis, genetics, osmosis-diffusion and cell divisions, but lesser parts of the "Systems" topic are concerned. (Bahar, 2002).

In terms of teaching biology, the topic "Digestive system" is useful in learning other systems and subjects. Learning each system plays an essential role in learning another system (Ürey ve Çalık, 2008). To give an example: students can define the gut as an excretory organ. Thus, when the issues and concepts related to the excretory system are learned, the wrong preliminary information will cause new misconceptions. All systems in the body can be considered as a system, the topics of each system can be evaluated analytically. Thus, the issues and concepts of the digestive system will be learned before the misconception occurs (Cerrah Özsevgeç, Artun \& Ünal, 2012).

Many studies on the digestive system identified the misconceptions of students (Harahap, Darussyamsu, Yuniarti, \& Ristiono, 2019; Güngör \& Özgür, 2009; Çakıc1, 2005; Carvalho, Silva, \& Clément, 2003; Banet \& Nünez, 1997; Nünez \& Banet, 1997, Clement \& Tunnicliffe, 2002). In the studies carried out in several countries about the digestive system in human beings, misconceptions such as defining the digestive system as 'a pipe with two open ends', defining the stomach as 'a balloon with no relationship with the mouth, having neither an entrance nor an exit', and expressing the stomach as an essential organ of the digestive system, were given as epistemologically rooted misconceptions (Carvallo, Silva, \& Clement, 2003). In the researches, such misconceptions were found in individuals with different cultures in different countries (Carvallo, Silva, \& Clement, 2003). In their study, Güngör and Özgür (2009) presented that the students established an incorrect relationship between the digestive system and the urinary system. From the drawings of the students, it was seen that the relationship that they established between the digestive and urinary systems was not a relationship that took place through the circulation system but a relationship in the form of direct connections between the digestive and urinary organs (Çardak, 2015).

Özkan (2017), in his study with seventh-grade students in nine secondary schools, aimed to detect misconceptions by developing a two-stage test on the Digestive System. The study sample consists of 413 students. A two-step test with 20 questions was applied. As a result of the applied test, students' misconceptions determined. As an example of the misconceptions identified: "Gastric sap water digests all nutrients.", "The organ where digestion ends is the large intestine", "Physical digestion takes place only in the mouth", "Digestion is completed in the anus", etc. It is not possible to conclude whether the misconceptions stem from students or teachers.

No research on misconceptions in the field of biology has been found in Kosovo. Therefore, this study is the first study in Kosovo, so it is crucial. As it is a comparative education study, in terms of detecting misconceptions with the cultural origin; Also, knowing the misconceptions of different ethnic groups on the subject is vital in terms of planning education and training activities.

In biology teaching, it is seen that misconceptions that are resistant to change an obstacle for students to perceive and comprehend new information. Studies with misconceptions have shown that students need a certain amount of time to eliminate wrong concepts. If misconceptions that existed in students could be identified before they started teaching, it would be easier to overcome them during teaching.

Structures defined as learning disabilities are useful in determining the origins of misconceptions. For this purpose, Brousseau (1986) classifies the misconceptions that cause learning disabilities according to their origin and gather them under four main titles. These:

- Epistemological misconceptions

- Cultural misconceptions

- Misconceptions of didactic origin

- Ontogenetic misconceptions. 
This study aims to determine the misconceptions of 12th-grade students about "Digestive System in Human" comparatively. Possible causes of misconceptions detected were tried to be determined. For this purpose, data were collected from high school 12th-grade students $(\mathrm{n}=150)$ of three different ethnic origins (Turkish, Albanian and Bosnian) in Kosovo.

\subsection{Place of Digestive System in Human in the Education System of Kosovo}

The official language in Kosovo is Albanian, Serbian and English. According to the Constitution, Turkish is used as the official language in the municipalities where the Turkish society lives densely. Therefore, in these regions, Turkish education is provided in the mother tongue, from kindergarten to graduate education. In this study, while collecting data, it was paid attention that the students are students who study in their mother tongue. Thus, cultural misconceptions were tried to be determined.

In Kosovo, the primary school takes five years, middle school four years and high school for three years. Grades with the digestive system subject and content in the curriculum are given in Table 1. Looking at this table, in the formal education process, when students come to the 12th grade, they see the digestive system three times in the 3rd, 9th, and 11th grades and the 10th grade in the Health Vocational High School.

Table 1. The Digestive System in Kosovo Education System

\begin{tabular}{|c|c|c|}
\hline School Level & Grade & Content in the Curriculum \\
\hline $\begin{array}{l}\text { Primary } \\
(5 \text { years })\end{array}$ & 3rd grade & $\begin{array}{l}\text { No information is available anatomically and physiologically. It } \\
\text { can be considered as a preparation. }\end{array}$ \\
\hline $\begin{array}{l}\text { Middle } \\
\text { (4 years) }\end{array}$ & $9^{\text {th }}$ grade & $\begin{array}{l}\text { Superficially, there are anatomy and physiology of the digestive } \\
\text { system. }\end{array}$ \\
\hline $\begin{array}{l}\text { High } \\
\text { (3 years) }\end{array}$ & $\begin{array}{l}\text { Science High School } \\
\left(11^{\text {th }} \text { grade }\right)\end{array}$ & $\begin{array}{l}\text { There are } 2 \text { hours of biology per week. The anatomical and } \\
\text { physiological features of the digestive system are studied in detail. }\end{array}$ \\
\hline & $\begin{array}{l}\text { Health Vocational High } \\
\text { School } \\
\left(10^{\text {th }} \text { grade and }\right. \\
\left.11^{\text {th }} \text { grade }\right)\end{array}$ & $\begin{array}{l}\text { The 10th grade has } 2 \text { hours of Anatomy and Physiology lessons per } \\
\text { week, and the } 11 \text { th grade has } 1 \text { hour of biology lessons per week. } \\
\text { The anatomical and physiological features of the digestive system } \\
\text { are studied in detail. }\end{array}$ \\
\hline
\end{tabular}

\section{Method}

2.1 Sample

In Kosovo, in the 2016-2017 academic year, the Department of General Nursing / Technician at the "Luciano Motroni" Health Vocational High School in Prizren province (Turkish, Albanian, Bosnian), Science department from the "GjonBuzuku" Science High School (Turkish, Albanian, Bosnian), in Pristina province "Sami Frasheri"was conducted with the students of "Atatürk" Science High School Science Department in Turkish, Mamuşa "Science High School" in Science Department. Data collected from 50 Turkish, 50 Albanian, and 50 Bosnian students studying in high school seniors in different high schools. The distribution of the sample is given in Table 2 .

Table 2. Distribution of the Sample by Cities and Ethnicity

\begin{tabular}{lcccc}
\hline & Prizren & Priştine & Mamuşa & Total \\
\hline Turkish & 30 & 10 & 10 & 50 \\
Bosnian & 50 & - & - & 50 \\
Albanian & 50 & - & 10 & 50 \\
Total & 130 & 10 & & 150 \\
\hline
\end{tabular}

\subsection{Data Collection Tool}

In this study, the following form was given to the students to determine the misconceptions of "Human Digestive System". There are two sections in the form.

In the first part, the figure of an empty body with the bagel and tea on hand given and then asked to draw the path on an empty body. To the areas left behind in the digestive system, and to explain on the side. By making a descriptive analysis of expressions, misconceptions were tried to categorize. The general situation also evaluated students, and their answers were interpreted and marked in the relevant categories determined beforehand. 


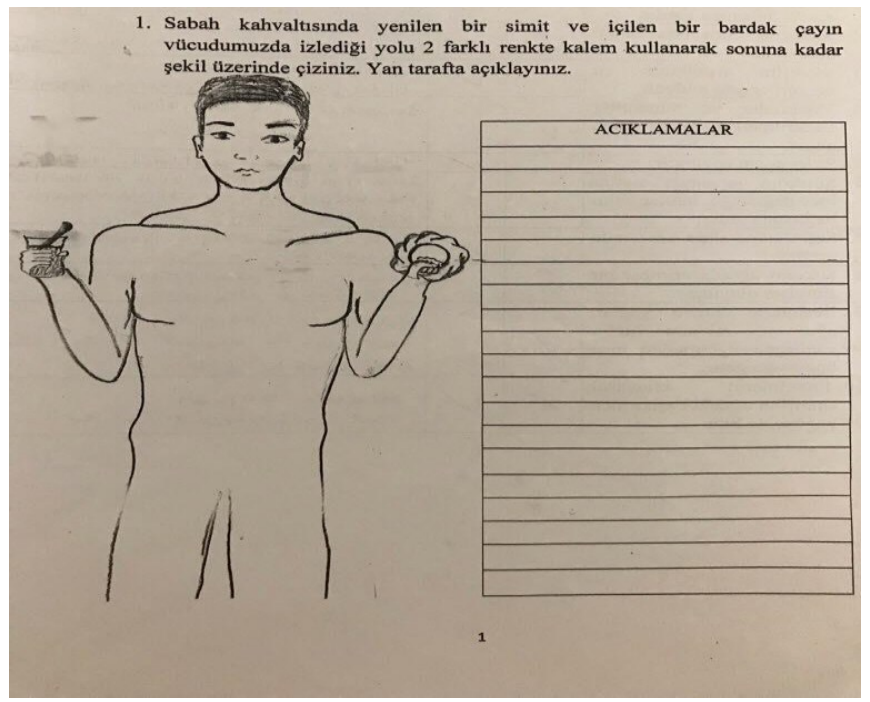

Figure 1. Data Collection Tool of Drawing and Explanation Form

In the second part, ten items about the digestive system are given. As seen in Table 3, the students mark the items as "True" or "False". Make an explanation on the side of this answer.

Table 3. Items Related to the Digestive System in the Second Part of the Data Collection Tool

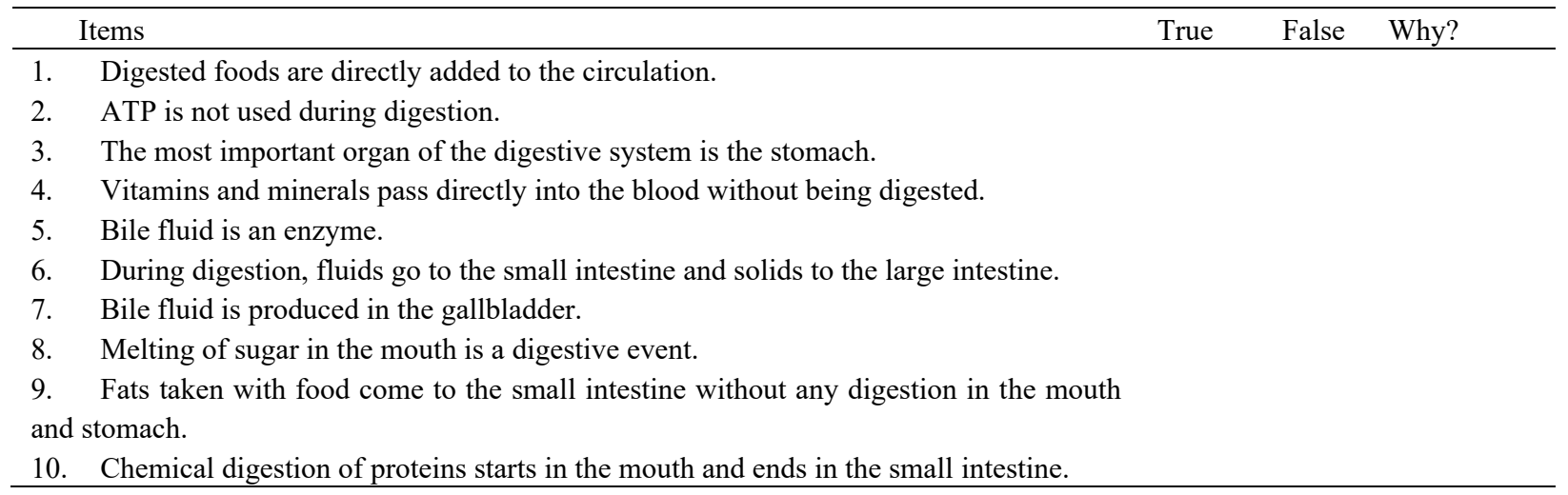

The data collection tool was translated and implemented in Albanian, Bosnian and Turkish languages.

\subsection{Data Analysis}

\subsubsection{Analysis of Student Drawings and Explanations}

Fourteen categories created from the drawings made by students with the anatomy and physiology of the digestive system. The first nine categories are related to the anatomy of the digestive system organs. It is possible to see information about the location of organs and their relationship with other organs in these categories. Categories 10-13 include categories related to the physiology of digestion. The 14th category is the category that does not contain misconceptions about the digestive system and has the closest answer to scientific knowledge. Descriptions of these categories given in Table 4. 
Table 4. Students Drawing Categories

\begin{tabular}{ll}
\hline Category No & Descriptions \\
\hline Category 1 & $\begin{array}{l}\text { Drawing of the digestive system in the form of two open-ended pipes with only one beginning } \\
\text { and end }\end{array}$ \\
Category 2 & $\begin{array}{l}\text { Drawing of the digestive system as an open/closed structure, starting in the mouth and ending } \\
\text { in a bag-shaped stomach/intestine }\end{array}$ \\
Category 3 & $\begin{array}{l}\text { Drawing of the digestive system in the form of two different pipes from the mouth } \\
\text { Category } 4\end{array}$ \\
Category 5 & $\begin{array}{l}\text { Drawing and explaining the digestive system as pipes separately for liquid and solid after } \\
\text { stomach }\end{array}$ \\
Category 6 & $\begin{array}{l}\text { Drawing of the digestive system in connection with kidney and intestine } \\
\text { Category } 7\end{array}$ \\
relation to each other \\
Category 8
\end{tabular}

Of the categories given in Table 4, only the 14th category represents the full truth. All other categories correspond to one or more misconceptions.

\subsubsection{Analysis of the Items Given about the Digestive System}

In the second part of the data collection form, ten items that were given to the students to answer (Table 3). They were asked to tick the "true" or "false" box and were expected to explain their answers. Frequency analyzes were made by classifying their answers as scientifically correct, scientifically wrong, or empty. In analyzing this question, students were assumed to have misconceptions about the items they scientifically answered incorrectly. Besides, those who made a false explanation, although they marked the scientifically correct option, were also tried to determine the possible misconceptions.

\section{Results}

In this section, the findings of the two sections in the data collection tool are given separately.

\subsection{Student Drawings and Explanation Findings}

A frequency analysis of 150 students' drawings about the digestive system was made. Some students' drawings fall into more than one category. All categories, except category 14, contain misconceptions at different levels and origins. Category 14 is the correct answer without misconception. In this category the digestive system organs are those drawn incomplete, correct order, right location, and relatively correct proportion. The artistic dimensions of the drawings are ignored. The data in Table 5 were obtained only from the analysis of the drawings. 
Table 5. Distribution of Turkish, Albanian and Bosnian Students' Drawings by Category

\begin{tabular}{|c|c|c|c|}
\hline Categories & $\begin{array}{l}\text { Turkish } \\
(\mathrm{n}=40)\end{array}$ & $\begin{array}{l}\text { Albanian } \\
(\mathrm{n}=50)\end{array}$ & $\begin{array}{c}\text { Bosnian } \\
(\mathrm{n}=50)\end{array}$ \\
\hline \multicolumn{4}{|l|}{ Category 1} \\
\hline $\begin{array}{l}\text { Drawing of the digestive system in the form of two open-ended pipes } \\
\text { with only one beginning and end }\end{array}$ & $\% 12$ & $\% 16$ & $\% 36$ \\
\hline \multicolumn{4}{|l|}{ Category 2} \\
\hline $\begin{array}{l}\text { Drawing of the digestive system as an open/closed structure, starting in } \\
\text { the mouth and ending in a bag-shaped stomach/intestine }\end{array}$ & $\% 4$ & $\% 30$ & $\% 4$ \\
\hline \multicolumn{4}{|l|}{ Category 3} \\
\hline $\begin{array}{l}\text { Drawing of the digestive system in the form of two different pipes from } \\
\text { the mouth }\end{array}$ & $\% 2$ & $\% 0$ & $\% 0$ \\
\hline \multicolumn{4}{|l|}{ Category 4} \\
\hline $\begin{array}{l}\text { Drawing and explaining the digestive system as pipes separately for } \\
\text { liquid and solid after stomach }\end{array}$ & $\% 8$ & $\% 22$ & $\% 22$ \\
\hline \multicolumn{4}{|l|}{$\begin{array}{l}\text { Category } 5 \\
\text { Digestion system, stomach, and kidney-related drawing }\end{array}$} \\
\hline \multicolumn{4}{|l|}{ Drawing of the digestive system in connection with kidney and intestine } \\
\hline \multicolumn{4}{|l|}{ Category 7} \\
\hline $\begin{array}{l}\text { Drawing of the digestive system in the form of organs (nutrients in the } \\
\text { space) that have no relation to each other }\end{array}$ & $\% 2$ & $\% 0$ & $\% 0$ \\
\hline $\begin{array}{l}\text { Category } 8 \\
\text { Drawing of the digestive system in the form of an end with the bladder }\end{array}$ & Drawing of the digestive system in the form of an end with the bladder & $\% 0$ & $\% 2$ \\
\hline \multicolumn{4}{|l|}{ Category 9} \\
\hline $\begin{array}{l}\text { Drawing of the digestive system in the form of an end with the small } \\
\text { intestine (Anus-connected) }\end{array}$ & $\% 8$ & $\% 32$ & $\% 18$ \\
\hline \multicolumn{4}{|l|}{$\begin{array}{l}\text { Category } 10 \\
\text { Food is only digested in the stomach }\end{array}$} \\
\hline \multicolumn{4}{|l|}{ Tea is filtered in the duodenum } \\
\hline \multicolumn{3}{|l|}{ Food boils in the stomach and small intestine } & $\% 36$ \\
\hline \multicolumn{4}{|l|}{ Category 13} \\
\hline $\begin{array}{l}\text { Anatomically and physiologically correct description of the digestive } \\
\text { system, except absorption }\end{array}$ & $\% 10$ & $\% 12$ & $\% 32$ \\
\hline \multicolumn{4}{|l|}{ Category 14} \\
\hline $\begin{array}{l}\text { Anatomically and physiologically correct description of the digestive } \\
\text { system }\end{array}$ & $\% 10$ & $\% 2$ & $\% 4$ \\
\hline
\end{tabular}

The findings obtained as a result of the analyzes are as follows:

Category 1: It is a common misconception in the literature that its digestion system is drawn and explained as two open pipes (Clemént \& Tunnicliffe, 2002; Giordan \& Vecchi, 1987; Özgür \& Pelitoğlu, 2008; Güngür \& Özgür, 2009; Güngör, 2009). This misconception was observed in $36 \%$ of Bosnian students, $16 \%$ of Albanian students, and $12 \%$ of 
Turkish students.

In the explanations, the students stated that "we take the food by mouth and discard or empty it with the anus". So the digestive system is like a pipe. There is no leak on the system. None of the students with this misconception mentioned the absorption in their explanations. This misconception with an epistemological origin is an expected result to be seen in students belonging to three different ethnic groups. As it is known, since the misconceptions of epistemological origin are related to the ontological processes of knowledge, it is natural that they exist in every society regardless of cultures. There is an example in Figure 2.

Category 2: The digestive system starts with the mouth and ends with a bag-shaped stomach, as well as being an epistemological misconception, it is sometimes a cultural dimension (Özgür \& Pelitoğlu, 2008; Güngür \& Özgür, 2009; Güngör, 2009).

In this study, this misconception was found in 30\% of Albanian students and 4\% of Turkish and Bosnian students. As a reason for this misconception, it may be since the stomach is more than necessary. Most societies have idioms about the stomach. For example: "It sticks in my gizzard", "My stomach is scraping", "Heartburn", "Swell like a balloon," etc. Since these idioms are frequently encountered in our daily life, it may cause students to think that the stomach is the essential organ of our digestive system and even our digestive system is the stomach. There is an example in Figure 2.

Category 3: Drawing of the digestive system in the form of two different pipes from the mouth is the misconception seen in a single Turkish student. This misconception has not been found in Albanians and Bosnians.

Category 4: The misconception of drawing individual pipes after the stomach for liquids and solids was $8 \%$ in Turkish students and 22\% in Albanian and Bosnian students. This misconception may be related to the concept of prima de perception. When students are asked about the changes in the digestive system, one solid and one liquid, and the way they follow, they should follow a separate route for the two foods. Especially if the concepts of the small intestine and large intestine are not fully understood, this situation is likely to occur. There is an example in Figure 2.

Category 5: The misconception of "drawing the digestive system in connection with stomach and kidney" is seen in $6 \%$ of Turkish students and $2 \%$ of Bosnian students. This misconception has not been found among Albanian students.

Category 6: While the misconception of "drawing the digestive system in connection with kidney and intestine" was observed with a maximum of $16 \%$, it was observed in $8 \%$ of Albanian students and $4 \%$ of Bosnian students. There is a misconception that fluids in the digestive system should be removed directly through the urinary tract. It is not expected that these misconceptions, which have an epistemological origin, will appear mostly in Turkish students. These misconceptions, which seem to have acquired a cultural dimension, may have resulted from the educational activities of Turkish students.

Category 7: The drawing of the digestive system as "organs that have no relation to each other (Nutrients in space)" is the misconception seen in a single Turkish student. This misconception has not been found in Albanians and Bosnians.

Category 8: The misconception of "drawing the digestive system in the form of ending with the bladder" was observed in $6 \%$ of Turkish students and $2 \%$ of Bosnian students. This misconception has not been found among Albanian students. There is an example in Figure 2.

Category 9: The misconception of the digestive system with the small intestine, in other words, the misconception that there is no large intestine in the digestive system was observed in $32 \%$ of Albanian students, $18 \%$ of Bosnian students and $8 \%$ of Turkish students. There is an example in Figure 2.

Category 10: Food is digested only in the stomach; the misconception is $36 \%$ in Albanian students, $10 \%$ in Turkish students, and only $2 \%$ in Bosnian students. These results are compatible with the findings in category two. Albanian students appear to have significant misconceptions about the stomach.

Category 11: There was a misconception that only $8 \%$ of Bosniak students had. "Tea is filtered in the duodenum". No such misconception has been encountered in the literature before. Possible causes of this misconception need to be explored separately.

Category 12: Another exciting misconception is "Food boils in the stomach and small intestine". We see that it is a concept used throughout Kosovo. This concept, which we encounter most in Bosnian students (36\%), is 10\% and 12\% in Turkish and Albanian students, respectively. The boiling of foods is used instead of digestion of foods. Such use will increase confusion between concepts. Besides, the fact that this concept used by Bosnian students is seen in 
other ethnic groups can only be explained by a close intercultural interaction.

Category 13: The misconception that "absorption is not part of digestion" is a common situation we see. If the digestive system looks like a tube at both ends (Category 1), absorption naturally needs to be ignored. Because the structure we call pipes is a leak-proof object in daily life. If the digestive system is perceived as a pipe system, then nothing should leak. Foods taken from above should come out from below.
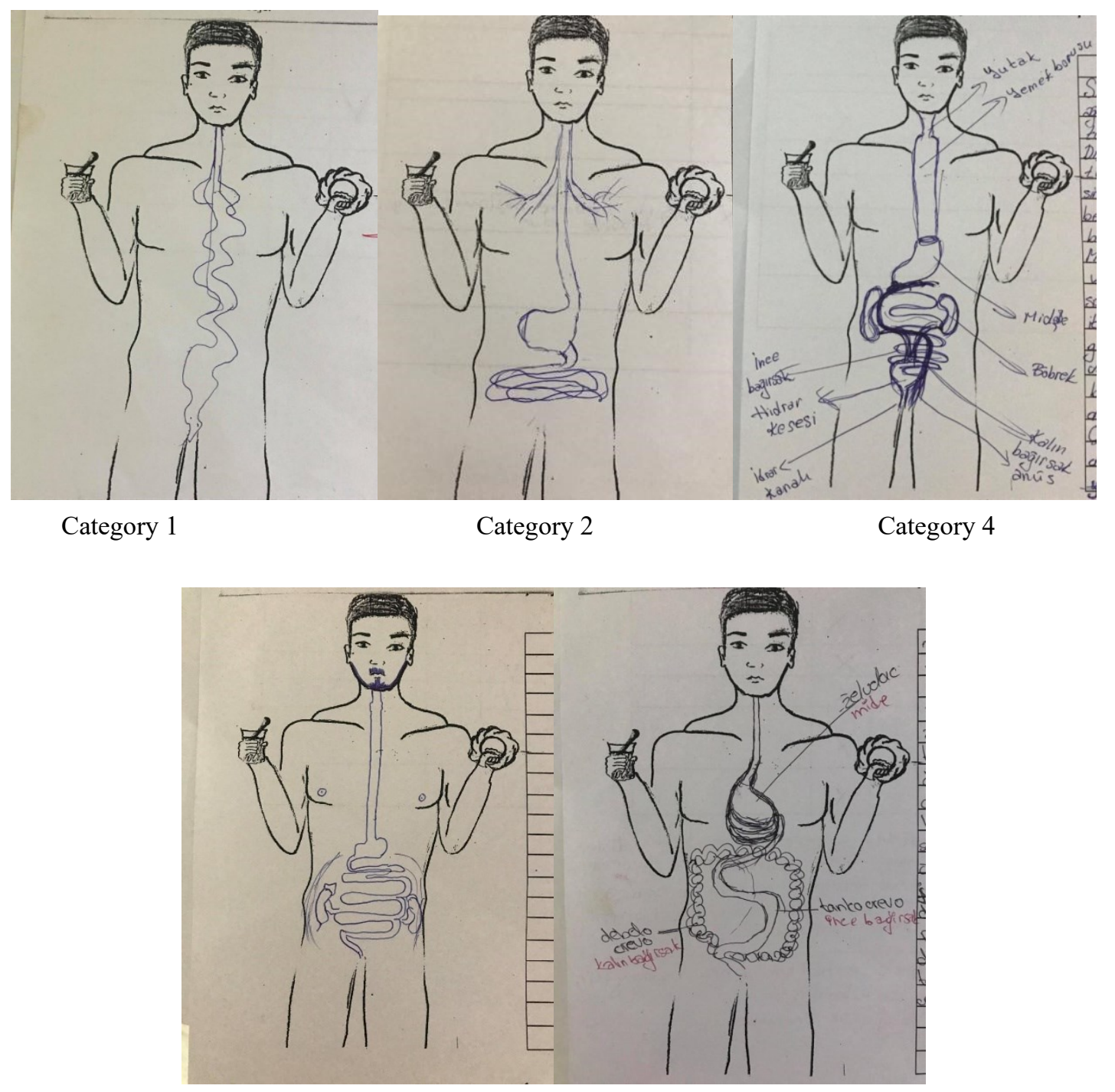

Category 8

Category 9

Figure 2. Drawing Samples of Different Categories

\subsection{Findings Related to the Answers Given to the Items Related to the Digestive System}

The second part of the form contains ten items related to the digestive system. Students marked whether these propositions were true or false. Then they explained why they thought so. These markings and explanations are categorized as scientifically correct answers, although the correct markings made, the answers are given incorrectly, and wrong answers are categorized. Some students did not respond to the items. The distribution of the answers given by Turkish, Bosnian, and Albanian students to the items are given in Table 6. 
Table 6. Distribution of Turkish, Albanian and Bosnian Students According to Their Answers to Items

\begin{tabular}{|c|c|c|c|c|c|c|}
\hline \multirow[t]{2}{*}{ Items } & \multicolumn{2}{|c|}{$\begin{array}{l}\text { Turkish } \\
\text { Students } \\
(\mathrm{n}=50)\end{array}$} & \multicolumn{2}{|c|}{$\begin{array}{l}\text { Albanian } \\
\text { Students } \\
(\mathrm{n}=50)\end{array}$} & \multicolumn{2}{|c|}{$\begin{array}{l}\text { Bosnian } \\
\text { Students } \\
(n=50)\end{array}$} \\
\hline & $\begin{array}{l}\text { True/ True } \\
\text { but false } \\
\text { explanation }\end{array}$ & $\begin{array}{l}\text { Misconcep } \\
\text { tion }\end{array}$ & $\begin{array}{l}\text { True/ True } \\
\text { but false } \\
\text { explanation }\end{array}$ & $\begin{array}{l}\text { Misconc } \\
\text { eption }\end{array}$ & $\begin{array}{l}\text { True/ True } \\
\text { but false } \\
\text { explanation }\end{array}$ & $\begin{array}{c}\text { Misconc } \\
\text { eption }\end{array}$ \\
\hline $\begin{array}{l}\text { 1. Digested foods are directly added to the } \\
\text { circulation. }\end{array}$ & $19 / 9$ & 30 & $46 / 29$ & 4 & $47 / 13$ & 3 \\
\hline 2. ATP is not wasted during digestion. & 7 & 41 & 8 & 41 & 10 & 39 \\
\hline $\begin{array}{l}\text { 3. The most important organ of the digestive } \\
\text { system is the stomach. }\end{array}$ & $5 / 2$ & 44 & $2 / 1$ & 48 & $23 / 16$ & 27 \\
\hline $\begin{array}{l}\text { 4. Vitamins and minerals pass directly into the } \\
\text { blood without being digested. }\end{array}$ & 36 & 13 & 23 & 26 & 22 & 27 \\
\hline 5. Bile fluid is an enzyme. & 12 & 33 & 7 & 42 & 17 & 32 \\
\hline $\begin{array}{l}\text { 6. During digestion, fluids go to the small } \\
\text { intestine and solids to the large intestine. }\end{array}$ & $18 / 6$ & 32 & 6 & 44 & $38 / 11$ & 11 \\
\hline 7. Bile fluid is produced in the gallbladder. & $4 / 1$ & 45 & 5 & 32 & 28 & 21 \\
\hline $\begin{array}{l}\text { 8. Melting of sugar in the mouth is a digestive } \\
\text { event. }\end{array}$ & 24 & 24 & $16 / 3$ & 34 & 37 & 11 \\
\hline $\begin{array}{l}\text { 9. Fats taken with food come to the small } \\
\text { intestine without any digestion in the mouth and } \\
\text { stomach. }\end{array}$ & $17 / 1$ & 30 & 9 & 41 & 5 & 44 \\
\hline $\begin{array}{l}\text { 10. Chemical digestion of proteins starts in the } \\
\text { mouth and ends in the small intestine. }\end{array}$ & $24 / 8$ & 24 & $28 / 12$ & 22 & 35 & 14 \\
\hline
\end{tabular}

Table 6 it is seen that the misconception of item 3 and item 7 in Turkish students has the highest value with $92 \%(\mathrm{n}=$ 46). It is possible to say that item 2 is $82 \%(\mathrm{n}=41)$ immediately after these proposals, while the minimum misconception rate is $26 \%(\mathrm{n}=13)$, and the item is 4 .

Looking at the answers of the Albanian students, it is seen that item 3 has the highest value with $98 \%(n=49)$. Item 6 shows close ratios with values of $88 \%(n=44)$, item $5,84 \%(n=42)$, item 2 and item 9 with $82 \%(n=41)$. Item 4 is the least misconception with $52 \%(\mathrm{n}=26)$.

When the answers of the Bosniak students are examined, it is seen that item 9 has the highest value, with $88 \%(\mathrm{n}=$ 44). Article 3 gets very close to item 9 with $86 \%(n=43)$. While item 2 is the closest item to these values with $78 \%$ $(\mathrm{n}=39)$, the misconception rate in item 8 with the lowest item $22 \%(n=11)$.

Looking at all these values, "The most important organ of the digestive system in the stomach." Regardless of the ethnicity of item 3, all students have one of the highest values. It is possible to say that this misconception is epistemological. Some of the answers given by students to this item are as follows:

\section{T22: "Foods digested from the stomach, passes circulation more quickly."}

\section{B27: "Because the food needs to come down to the stomach to boil."}

"Vitamins and minerals mix directly into the blood without being digested." Item 4, it is seen that 13 (26\%) of Turkish students, 26 (52\%) of Albanian students, 27 (54\%) of Bosniak students have misconceptions. This data suggests that Albanian and Bosnian students have similar misconceptions about this issue for a reason. In Turkish students, this proposition is the misconception that has the lowest level of misconception. 36 (72\%) Turkish Students gave close answers to scientific information. The number of Bosnian and Albanian students who answered correctly is close to the number of students with misconceptions. Another unusual situation in this article is that the explanations of the students who give the correct answer are correct. Some examples of misconceptions are as 
follows:

\section{A33: "Vitamins and minerals digested first." \\ T17: "After the large intestine, they pass into the blood." \\ B11: "They need to be digested/boiled."}

Considering item 1, item 8 and item 10, it is seen that Bosnian students' misconceptions of these items are $32 \%$ $(\mathrm{n}=16), 22 \%(\mathrm{n}=11)$ and $28 \%(\mathrm{n}=14)$, respectively. What is interesting here is that Turkish and Albanian students have at least $64 \%$ misconceptions in these items. Scientifically correct answers of Bosnian students to these items are quite higher than Turks and Albanians. Some of the examples of misconceptions are as follows:

Item 1 (Foods that digested participate directly in the circulation.)

T22: "Joins the circulation after the small intestine."

A47: "After the stomach passes into the large intestine."

B35: "Food is stored in the stomach first."

Item 8 (Melting of sugar in the mouth is a digestive event.)

A27: "Absolutely, because digestion starts in the mouth."

Item 10 (Chemical digestion of proteins starts in the mouth and ends in the small intestine.)

\section{T22: "Chemical digestion starts in the large intestine."}

A23: "It starts in the stomach and ends in the large intestine."

From the analysis of the second question, many misconceptions are belonging to each ethnic group. The causes of these can be analyzed separately. No research similar to this research has been carried out in Kosovo yet. Considerable results obtained in terms of the education system in Kosovo. Education about the digestive system at different levels in schools established for different purposes does not reach their goals. Extensive research needs to be done about why these misconceptions could not be eliminated or why they occurred.

\section{Discussion}

When the findings obtained according to the results of the research are analyzed, students from three ethnic origins have misconceptions. When these misconceptions were categorized, it is seen that some misconceptions were standard for all three ethnicities. These misconceptions seem to be of epistemological origin. This information, which is built as a result of daily life, is taken for granted and used as scientific information.

Some of the misconceptions of the students who are studying in the last year of high school are specific to a particular ethnic group. Also, misconceptions of cultural origin, which originate from the three ethnic groups living together and affect each other, were encountered.

It is not expected that Turkish students' misconceptions of the expression of "drawing the digestive system as an open/closed structure with only one beginning and end with two ends open in an open tubular stomach / intestine" is $12 \%$. It is an epistemological origin misconception.

The category of "drawing the digestive system as an open/closed structure that starts in the mouth and ends in a bag-shaped stomach/intestines" is the highest among the three ethnic groups in Albanian students. Students finish digesting nutrients in the stomach or intestines. These kinds of misconceptions among students arise from the fact that biology subjects are very related to daily life. They are seen in the dimension of cultural misconceptions.

As an advantage of performing a comparative study, some misconceptions were found to be specific for some students. For example: Although Bosnian students use the concept of "Digestive system" for the system, they use the concept of "boiling" to the digestion of nutrients in the stomach. This situation is mostly seen in Bosnian students. They appear to have a misconception of cultural origin. Various elements such as the culture, language, religion, traditions and customs, proverbs, and idioms of a nation affect the emergence of these misconceptions.

Subjects such as the human body and systems in biology education are directly related to our daily life. Formal education, before encountering such issues, there is information obtained from students' family, media, and their own lives. Besides, the language used when processing a subject, the experiments performed during the subject expression, the shapes used can cause misconception and incomprehension of the concepts during the learning of the subject. This research also shows that students from different ethnic origins have a culturally originated concept that 
originates from the language, traditions, and customs they use. There are also partnerships brought together by life; textbooks encountered formal education, language used by the teacher, and similar misconceptions stemming from visuals.

In Dry (1998), as a result of his work on misconceptions in science through the example of the human digestive system, he stated that the teaching process would make it easier for teachers to have a list of misconceptions determined in the literature. It is suggested that this issue should be addressed by considering these misconceptions in the design of course programs and classroom education activities during book writing. Abimbola \& Baba (1996) examined the misconceptions in the biology textbooks and determined that the misconceptions related to the digestive system were the second subject containing the misconception with $14.5 \%$ and $20 \%$ immediately after breathing and energy. When designing teaching, the teacher needs to be aware of these learning disabilities by textbook authors. The study of previous misconceptions will benefit those designing the teaching. The results of this study can also guide teachers who teach different ethnicities. As in this study, misconceptions of cultural origin can be determined by comparative studies.

It should not be forgotten that today's scientific knowledge will be the misconception of tomorrow.

\section{Acknowledgments or Notes}

This study is presented as a master thesis.

\section{References}

Ahi, B. (2017). Thinking about digestive system in early childhood: A comparative study about biological knowledge. Cogent Education, 4(1). https://doi.org/10.1080/2331186X.2017.1278650

Akpınar, E. (2006). Fen Öğretiminde Soyut Kavramların Yapılandırılmasında bilgisayar desteği: yaşamımızı yönlendiren elektrik ünitesi (Unpublished doctoral dissertation). Dokuz Eylül Üniversitesi Eğitim Bilimleri Enstitüsü, İzmir.

Bachelard, G. (1938). La formation de I'esprit scientifique. Paris: Vrin.

Banet, E., \& Nunez, F. (1997). Teaching and learning about human nutrition: A constructivist approach. International Journal of Science Education, 19(10), 1169-1194. https://doi.org/10.1080/0950069970191005

Bilgin, İ., Uzuntiryaki, E., \& Geban, Ö. (2003). Student's Misconceptions on the Concept of Chemical Equilibrium. Ĕgitim ve Bilim Dergisi, 29(127), 10-17.

Brousseau, G. (1986). Fondements et méthodes de la didactique des mathématiques. Recherches en didactique des mathématiques, 7(2), 33-115.

Carvalho, G. S., Silva, R., \& Clément, P. (2003). Epistemological and didactical learning obstacles identified in Portuguese primary school pupils (Synopsis), Research, and the Quality of Science Education. ESERA, Noordwijkerhout, CD.

Cerrah, L., Özsevgeç, T., \& Ayas, A. (2005). Biyoloji öğretmen adaylarının lise öğretim program konusundaki bilgi düzeyleri: Trabzon örneklemi. İn̈̈nü Üniversitesi Eğitim Fakültesi Dergisi, 6(9), 15-25.

Cerrah Özsevgeç, L., Artun, H., \& Ünal, M. (2012). The effects of the Swedish knife model on students' understanding of the digestive system. Asia-Pacific Forum on Science Learning and Teaching, 13(2), Article 5.

Clément, P., \& Tunnicliffe, S. D. (2002). Digestion / Circulation / Excretion: First results on the ontogenesis of the continuous tubing conception in U.K. pupils. Poster in Meeting ERIDOB, ENFA, Toulouse.

Çakici, Y. (2005). Exploring Turkish upper primary level pupils' understanding of digestion. International Journal of Science Education, 27(1), 79-100. https://doi.org/10.1080/0950069032000052036

Çardak, O. (2015). Student Science Teachers' Ideas of the Digestive System. Journal of Education and Training Studies, 3(5), 127-133. https://doi.org/10.11114/jets.v3i5.912

Dry, H. A. (1998). Student Misconceptions in Science: The Human Digestive System. Education and Human Development Master's Theses. 1084. Retrieved from https://digitalcommons.brockport.edu/ehd_theses/1084

Geerdts, M. S., Van de Walle, G. A., \& LoBue, V. (2015). Daily animal exposure and children's biological concepts. Journal of experimental child psychology, 130, 132-146. https://doi.org/10.1016/j.jecp.2014.10.001

Giordan, A., \& Devecchi, G. (1987). Les Origines du Savoir. Descnceptions des apprenants aux concepts 
scientifiques (Neuchatel- Paris: Delachaux and Niestl'e) [in French].

Güngör, B., \& Özgür, S. (2009). İlköğretim Beşinci Sınıf Öğrencilerinin Sindirim Sistemi Konusundaki Didaktik Kökenli Kavram Yanılgılarının Nedenleri. Necatibey Eğitim Fakültesi Elektronik Fen ve Matematik Eğitimi Dergisi, 3(2), 149-177.

Güngör, B. (2009). İnsanda sindirim sistemi konusunda ilkögretim 7. sinıf öğrencilerinin kavram yanılgılarının kökenlerinin belirlenmesine yönelik boylamsal bir çalışma (Unpublished Doctoral Dissertation). Balıkesir Üniversitesi Fen Bilimleri Enstitüsü, Balıkesir.

Harahap, F., Darussyamsu, R., Yuniarti, E., \& Ristiono, R. (2019). Identification of Misconceptions on Material of Food Digestive System in Humans Using Two Tier Multiple Choice Diagnostic Tests at SMPN 15 Padang. Atrium Pendidikan Biologi, 4(1), 84-94.

Kılıç, D., \& Sağlam, N. (2004). Biyoloji eğitiminde kavram haritalarının öğrenme başarısına ve kalıcılığına etkisi. Hacettepe Üniversitesi Ĕ̈itim Fakültesi Dergisi, 27, 155-164.

Nunez, F., \& Banet, E. (1997). Students' conceptual patterns of human nutrition. International Journal of Science Education, 19(5), 509-526. http://dx.doi.org/10.1080/0950069970190502

Özgür, S., \& Çıldır Pelitoğlu, F. (2008). İlköğretim 6. sınıf öğrencilerin "Sindirim sistemi" konusu ile ilgili didaktik kökenli kavram yanılgılarının incelenmesi. Kuram ve Uygulamada Ĕgitim Bilimleri, 8(1), 117-159.

Özkan, F. (2017). 7. Sinıf sindirim sistemi konusunda iki aşamalı test geliştirilerek kavram yanılgılarının tespit edilmesi (Master Thesis). Erciyes Üniversitesi, Kayseri.

Pelitoğlu, F. (2006). İlköğretim 6. Sinıf Sindirim Sistemi Konusunun Transpozisyon Didaktik Teorisine Göre Incelenmesi (Master Thesis). Balıkesir Üniversitesi, Balıkesir.

Roswati, N., Rustaman, N. Y., \& Nugraha, I. (2019). The Development of Science Comic in Human Digestive System Topic for Junior High School Students. Journal of Science Learning, 3(1), 12-18. https://doi.org/10.17509/JSL.V3I1.18120.G10614

Selvi, M., \& Yakışan, M. (2004). Üniversite birinci sınıf öğrencilerinin enzimler konusu ile ilgili kavram yanılgıları. Gazi Üniversitesi Gazi Eğitim Fakültesi Dergisi, 24(2), 173-182.

Tekkaya, C., Çapa, Y., \& Yılmaz Ö. (2000). Biyoloji öğretmen adaylarının biyoloji konularındaki kavram yanılgıları. Hacettepe Üniversitesi Ĕgitim Fakültesi Dergisi, 18, 140-147.

Tekkaya, C., \& Balcı, S. (2003). Öğrencilerin fotosentez ve bitkilerde solunum konularındaki kavram yanılgılarının saptanması. Hacettepe Üniversitesi Ĕ̈itim Fakültesi Dergisi, 24, 101-107.

Ürey, M., \& Çalık, M. (2008). Combining different conceptual change methods within the 5E model: a sample teaching design of 'cell' concept and its organelles. Asia-Pacific Forum on Science Learning and Teaching, 9(2), 12. 